\title{
El Sesquicentenario del "Papel Periódico" de la Habana
}

$F^{N}$ este año se ha celebrado en Cuba el sesquicentenario la Isla. Fué el Papel Periódico de la Habana, cuyo primer número apareció el día 24 de octubre de 1790. Antes había habido en Cuba publicaciones periódicas como El Pensador y la Gazeta de la Havana, pero de la primera no se conserva ningún ejemplar, y de la segunda se sabe positivamente que fué sólo un papel de cuatro páginas destinado a la publicación de noticias oficiales y mercantiles. (1) No puede discutirse, pues, la primacía cronológica del Papel Periódico en la historia del periodismo en Cuba. Tuvo éste que ser, particularmente en sus primeros años, una publicación modestísima por su contenido $\mathrm{y}^{\mathrm{y}}$ hasta por los medios materiales de que disponían sus redactores; pero no por esto dejó de desempeñar un papel muy importante en el progreso de la cultura local y particularmente en la evolución literaria del país.

La obra de gobierno de don Luis de las Casas, uno de los mejores funcionarios que envió España a sus colonias, determinó una transformación tan amplia y tan rápida en la hasta entonces aletargada vida de la Isla, que los historiadores con notable unanimidad han seleccionado entre muchos hechos el gobierno de Las Casas para marear el comienzo de una época, la primera de importancia en la historia de Cuba. Una de las múltiples reformas y adelantos del gobierno de Las Casas fué la utilización de la imprenta - introducida en la Habana 
desde 1723, por lo menos-para la publicación del Papel Periódico, puesto desde sus orígenes bajo la dirección de una meritísima institución debida al mismo fundador, la "Sociedad de Amigos del País", Ilamada en aquellos tiempos primitivos de menos despierta suspicacia de las autoridades coloniales "Sociedad Patriótica".

El Papel Periódico fué, por consiguiente, uno de los síntomas más significativos de una época nueva en la historia de Cuba, síntoma que con otros determinan su profunda $y$ rápida transformación en poco más de un tercio de siglo. Hasta 1790, Cuba había sido una factoría, un depósito de mercancías y un punto de parada y enlace en el comercio y las relaciones administrativas entre una metrópoli europea y sus numerosas y extensísimas colonias americanas. Por espacio de tres siglos el cubano vivió esa vida de reflejos propia de toda factoría. Entonces el cubano vive en su isla, pero de espaldas a ella; mira sólo al mar; que le ha de traer, en las naves del rey, del pirata o del comerciante extranjero clandestino, la riqueza o la ruina. Cuba vive entonces a expensas de su favorable posición geográfica; no de lo que es, de lo que tiene, sino del lugar del mundo moderno en que está situada; pero desde la última década del siglo XVIII, las cosas cambian para ella por completo. La agricultura y la ganadería comienzan a dar el más seguro índice de la riqueza de los países americanos, y en lo porvenir la isla bien situada se incorpora rápidamente al conjunto de los países importantes de Hispanoamérica con títulos más efectivos que el de su envidiable $\mathrm{y}$ al mismo tiempo peligrosa ubicación. La nueva orientación económica del mundo determina el cambio; Las Casas, en definitiva, no es sino un excelente instrumento con el cual la operación se realiza.

En la frondosa y efímera floración de publicaciones periódicas cubanas durante siglo y medio, hay una serie de nombres respetables: el Papel Periódico, la Revista Bimestre, El Faro Industrial, El Siglo, la Revista de Cuba, la Revista Cubana. Y quien escriba la historia del periodismo en Cuba en relación con todo el proceso histórico de la Isla, no podrá desconocer que cada una de esas publicaciones culminantes marca un nuevo rumbo en la vida cubana a lo largo del siglo XIX. 
El Papel Periódico refleja en sus páginas las ansias de mejoramiento de las condiciones materiales de vida, anhelos que han de cristalizar, merced al esfuerzo de muchos de sus redactores en gran parte, en el rápido crecimiento de la riqueza y de la población y en mejoras elementales del régimen económico-social. Cuando al finalizar el primer tercio del siglo XIX, aparece la Revista Bimestre, patrocinada también por la "Sociedad Económica", y regida por el vigoroso y dialéctico talento de José Antonio Saco, la excelente publicación indica que la transformación material de la factoría en colonia con fuerte aspiración a una personalidad definida se ha operado ya, y que una transformación más honda, transformación espiritual de la naciente colectividad va a comenzar a operarse. En las páginas ya centenarias de la primitiva Revista Bimestre Cubana encontramos hoy la mejor documentación no sólo de un extraordinario progreso cultural, corolario del progreso económico, sino la integración de una conciencia colectiva, la sistematización de preclaros esfuerzos individuales en un pensamiento común, en un ideario cubano definido, que se volvía a considerar los graves problemas de la realidad insular. Entonces aparecen en rápida sucesión histórica esos "ismos" famosos que constituyen el espíritu, la razón de ser de la vida cubana durante el siglo pasado: esclavismo, anti-esclavismo, anexionismo, reformismo, autonomismo, separatismo. $\mathrm{Y}$ publicaciones como las arriba recordadas se constituyen en órganos de esas ideas en la segunda mitad del siglo. Por eso conmemorar el advenimiento de uno de esos periódicos vale tanto como evocar una época, porque cada uno de ellos, en la medida de sus circunstancias, es el órgano de una historia que hoy nos empeñamos en desentrañar y comprender.

El Papel Periódico es el venerable decano del grupo. En sus páginas lo predominante, lo que da la tónica de la publicación, es el ansia de mejoramiento material; si se permite la paradoja, un desinteresado utilitarismo de patricio provinciano, que es como el éspíritu común de sus redactores. El Papel Periódico encarna esa vigorosa aspiración de una minoría directora que impulsada por un pragmático primum vivere se afana por realizar una primaria transformación material 
de la vida colectiva. Vivir mejor, por el momento, es vender mejor los productos de la tierra hasta entonces olvidada; es tener mejores fincas y mejores ingenios, mejores casas, $y$ calles, si no más limpias, de tránsito más fácil para viandantes y mercaderías; es poseer una legislación más flexible, que estorbe menos con trabas arbitrarias las nacientes actividades del comercio. Todos ponen su esfuerzo al servicio de ese ideal: el capitán general Las Casas, el primeró; el economista Arango y Parreño; el médico Romay; altos funcionarios de complicadas atribuciones; graves eclesiásticos de cargos e incumbencias no menos complejas dentro del intrincado laberinto de mandos y potestades que fué el régimen colonial de España. Un mismo interés los impulsa; pero para cada individuo de aquel grupo selecto de patricios, ante el interés colectivo, no cabe otra reacción que el desinteresado renunciamiento al interés individual.

Entregados a estos afanes los redactores del Papel Periódico, la literatura desinteresada quedaba en principio fuera de sus columnas, o por lo menos relegada a lugar secundario. Pero la literatura es muy diversa, y como ciertos partidos políticos de nuestra época, posee formas muy distintas para adaptarse a las circunstancias de cada medio y de cada momento. $\mathrm{Y}$ entre las páginas del Papel fueron deslizándose aquellas producciones más literarias, que sin dejar de responder a las urgencias utilitarias, practicistas del tiempo, poseen cierto carácter artístico que se hermana mejor o peor, según los casos, con algún interés, siquiera sea de orden moral. Así aparecieron artículos de costumbres; prosa moralizadora; relatos breves que nos podemos permitir llamar crónicas; sátira; antecedentes de crítica literaria, que en el mejor de los casos no solía pasar de censura gramatical; versos festivos; y finalmente versos líricos, de un artificioso, casi mecánico lirismo neoclásico.

Pero juzgadas las cosas del único modo posible para la recta apreciación histórica, es decir en función de sus circunstancias, el viejo Papel Periódico merece nuestra veneración sin reservas porque fué el órgano de una época y de un medio con todas sus limitaciones; pero siempre con absoluta fideli- 
dad a su misión histórica. Tuvo ante sí como un deber una función social, y supo desempeñarla hasta el límite de sus posibilidades, y ello es ya una obra respetable y ejemplar que la posteridad tiene que reconocerle.

\author{
RaIMUNDo Lazo, \\ Universidad de la Habana.
}


